\title{
EFEKTIVITAS PROGRAM PENGEMBANGAN USAHA AGRIBISNIS PEDESAAN DALAM MEMBERDAYAAN MASYARAKAT MISKIN
}

\author{
Yulpia Winingsih \\ Universitas Islam Negeri Imam Bonjol Padang \\ Email: yulpiawiningsih@gmail.com \\ Sarwan \\ Universitas Islam Negeri Imam Bonjol Padang \\ Email: sarwanlubis@uinib.ac.id
}

\begin{abstract}
This article aims to uncover and analyze the achievement of objectives, accuracy of objectives, satisfaction, and success of rural agribusiness development programs in empowering the poor in the Pesisir Selatan, West Sumatera. This is a qualitative descriptive research type. A few poor communities are respondents of this research. Interview, observation and documentation use as data collection techniques. The results showed that the rural agribusiness development program has not been able to help the community as a whole because there are combinations of farmer groups that have been effective and there is a combination of farmer groups that have not been effective. Effective farmer group combinations are evidenced by increasing income, group members, and assets. While the combination of farmer groups that have not been effective is marked by community mentality that is difficult to change bad habit in using money for ineffective purposes. It is concluded that rural agribusiness development programs has not been succeed in empowering Pesisir Selatan community. The implication is poor community should be given more intensive community empowerment by government through more effective strategies.
\end{abstract}

Key Words: Empowering programs, rural agribusiness.

\section{PENDAHULUAN}

Kemiskinan merupakan masalah multidimensi yang dipengaruhi oleh berbagai faktor yang saling berkaitan, antara lain : tingkat pendapatan, kesehatan, pendidikan, akses terhadap barang dan jasa, lokasi geografis dan kondisi lingkungan (Dewi, Yusuf, \& Iyan, 2017; SADIYAH \& Arianti, 2012; Wijayanto \& Arianti, 2010). Oleh karena itu, pendekatan ekonomi dalam bentuk pemberdayaan menjadi salah satu strategi untuk pembangunan nasional. Pemberdayaan masyarakat merupakan salah satu pendekatan yang sering digunakan dalam meningkatkan kualitas kehidupan dan meningkatkan harkat martabat keluarga miskin (Sururi, 2017). Orang miskin tidak dipandang sebagai orang yang serba kekurangan dan objek pasif penerima pelayanan saja, melainkan sebagai orang yang memiliki beragam kemampuan yang dapat dimobilisasi untuk perbaikan hidupnya (I. Mustikawati, 2010; R. I. Mustikawati, Si, Baswedan, \& Sumardiningsih, n.d.; Narutomo, 2014; Rahmatika, 2018).

Pemberdayaan adalah suatu kegiatan dalam memberikan daya atau kekuatan kepada masyarakat yang tidak 
mampu dari seorang fasilitator kepada masyarakat agar masyarakat mampu mengambil keputusan sendiri apa yang terbaik untuk dirinya (Sudarsana, 2016). Dalam pemberdayaan banyak hal yang harus diperhatikan dan salah satu aspek terpentingnya yaitu aspek efektivitas suatu program pemberdayaan masyarakat (Miradj \& Sumarno, 2014). Selanjutnya, efektivitas merupakan penilaian terhadap hubungan target yang direncanakan dengan realisasi yang dicapai (Astuti, 2015; Suoth, Tinangon, \& Rondonuwu, 2016). Realisasi merupakan sebuah proses yang terdiri dari input dan output.

Mengukur efektivitas program dalam suatu lembaga mengacu kepada tujuan dan hasil akhir dari program yang telah dijalankan. Bila tujuan dari program tersebut tercapai, tepat sasaran atau tepat guna, maka program tersebut dikatakan efektif. Inilah yang menjadi indikator dalam menentukan efektif atau tidaknya suatu program yang dilaksanakan (Cambel, 1989). Teori efektivitas Chambel sengaja digunakan untuk mengukur efektif atau tidaknya program pengembangan usaha agribisnis pedesaan (PUAP) di Kabupaten Pesisir Selatan. PUAP adalah kegiatan dari Kementerian Pertanian dalam mengembangkan dan memberdayakan agribisnis petani di desa yang ditetapkan melalui Peraturan Menteri Pertanian nomor 273/kpts/OT.160/4/2007.

Sehubungan dengan uraian di atas, artikel ini bertujuan untuk mengungkapkan dan menganalisis keberhasilan program pengembangan agribisnis pedesaan dalam memberdayakan masyarakat miskin di Kabupaten Pesisir Selatan.

\section{METODE PENELITIAN}

Penelitian ini menggunakan pendekatan deskriptif kualitatif, dengan lokasi penelitian pada Kabupaten Pesisir Selatan. Data penelitian dikumpulkan melalui teknik wawancara, observasi dan dokumentasi. Sedangkan sumber data adalah gabungan kelompok tani agribisnis yang ada di Kabupaten Pesisir Selatan yang terpilih sebagai sampel. Data dianalisis sesuai dengan langkah-langkah analisis data kualitatif.

\section{HASIL PENELITIAN DAN PEMBAHASAN}

Pencapaian Tujuan Program PUAP Dalam Memberdayakan Masyarakat Miskin di Pesisir Selatan

Tujuan dari program PUAP adalah untuk mengurangi angka kemiskinan pada masyarakat miskin di perdesaan, selain mengurangi angka kemiskinan program PUAP juga berusaha menciptakan lapangan kerja dan mengembangkan usaha-usaha masyarakat yang terhambat dengan faktor permodalan untuk usahanya. Pesisir Selatan memiliki dua jenis usaha yang dimodali oleh dana PUAP.

Pertama, usaha Tanaman Pangan, tanaman pangan merupakan salah satu usaha unggulan pada anggota kelompok tani Pesisir Selatan, disebabkan Pesisir Selatan sebagian besarnya adalah bermata pencaharian petani. Penyaluran dana PUAP kepada anggota kelompok tanaman pangan adalah dengan cara sistem kredit dimana setiap anggota kelompok sebelum mengajukan permohonan penurunan dana, anggota kelompok telah membuat RUB (Rencana Usaha Bersama) dan RUA (Rencana 
Usaha Anggota) disana telah tercantum berapa banyak modal yang dibutuhkan. Setiap anggota mendapatkan bantuan modal sesuai dengan kebutuhannya masing-masing, pada usaha tanaman pangan pinjaman modal berkisar Rp. 500.000- 5.000.000-, sesuai dengan usahanya karena bantuan tersebut hanya sebagai penambahan modal dan bukan bantuan modal sepenuhnya. Pada usaha tanaman pangan memiliki kelompok tani terbanyak dari setiap gabungan kelompok tani (gabungan kelompok tani) yang ada disebabkan wilayah Pesisir Selatan termasuk daerah agraris budidaya.

Gabungan kelompok tani Taluak Tigo Sakato adalah kelompok yang paling banyak anggotanya dibandingkan gabungan kelompok tani lainnya (gabungan kelompok tani Semedang). Hal tersebut disebabkan wilayah Taluak Tigo Sakato lahan lepas (sawah) lebih dominan, sehingga usaha tanaman pangan merupakan salah satu usaha produktif budidaya andalan pada masyarakat Taluak Tigo Sakato. Sedangkan pada gabungan kelompok tani Semedang usaha tanaman pangan lebih sedikit dikarenakan kondisi wilayahnya yang didominasi oleh pantai.

Pelaksanaan program PUAP pada usaha tanaman pangan di Kabupaten Pesisir Selatan bila dirujuk kepada konsep efektivitas, seperti yang dipaparkan oleh Handayaningrat bahwa efektivitas merupakan sebuah pengukuran dimana suatu target telah tercapai sesuai dengan apa yang telah direncanakan. Beranjak dari konsep tersebut, dapat dilihat bahwa proses pelaksanaan program PUAP dalam memberdayakan masyarakat miskin di Kabupaten Pesisir Selatan pada 3 gabungan kelompok tani yang diteliti bahwa kedua Gabungan kelompok tani (Taluak Tigo Sakato dan Semedang) terindikasi efektif dengan indikator yang menunjukan dimana terdapat peningkatan pendapatan dengan usaha tanaman pangan melalui program tanam SRI (the System Rice of Intensification). Sedangkan pada gabungan kelompok tani Pincuran Bersama yang juga menjadi pengamatan penelitian terlihat belum efektif. Hal itu dibuktikan dengan sikap yang ditunjukan masyarakat yang dinilai belum baik. Kondisi ini terlihat dengan adanya ajakan dari ketua kelompok tani kepada anggotanya untuk tidak mengembalikan uang pinjaman kepada ketua gabungan kelompok tani karena menurut mereka bantuan tersebut adalah bantuan hibah bukan bantuan pinjaman.

Kedua, usaha Industri Rumah Tangga adalah salah satu usaha yang sering di geluti oleh ibuk-ibuk rumah tangga yang ada di Pesisir Selatan. Untuk melihat efektif atau tidak pelaksanaan program dalam suatu lembaga harus merujuk kepada tujuan dan hasil akhir dari program yang telah dijalankan, bila tujuan dari program tersebut tercapai, tepat sasaran atau tepat guna, maka program tersebut dikatakan efektif. Dalam hali ini gabungan kelompok tani Taluak Tigo Sakato dan Semedang telah dapat mewujudkan tujuan dari program PUAP dalam mengurangi angka kemiskinan dibuktikan dengan banyaknya anggota kelompok merasa terbantu dengan program PUAP. Pada gabungan kelompok tani Taluak Tigo Sakato dan Semedang telah mampu membantu masyarakatnya keluar dari garis kemiskinan. Sedangkan pada gabungan kelompok tani Pincuran Bersama belum efektif disebabkan mentalitas masyarakatnya yang susah diubah, dan 
adanya pengalihan tujuan dari dana pinjaman kepada keperluan sehari hari dan bahkan ada yang bersifat konsumtif.

Selain mengurangi angka kemiskinan yang menjadi tolak ukur pencapaian tujuan program PUAP adalah menciptakan lapangan pekerjaan. gabungan kelompok tani juga telah mampu melaksanakan tujuan lain dari program PUAP yaitu menciptakan lapangan pekerjaan. Pada pembentukan gabungan kelompok tani ini telah banyak membantu masyarakat dari yang tidak bekerja menjadi seseorang yang bisa menghasilkan uang setiap bulannya. Pada program gabungan kelompok tani telah berhasil membentuk atau memberikan lapangan kerja bagi masyarakat miskin di perdesaan. Lapangan kerja yang diberikan gabungan kelompok tani adalah dengan membentuk kepengurusan gabungan kelompok tani mulai dari ketua, sekretaris, bendahara, menejer LKM-A, anggota LKM-A 4 orang. Jadi bila disimpulkan gabungan kelompok tani telah mampu memberikan pekerjaan kepada 8 orang sebagai kepengurusan Gabungan kelompok tani dalam satu Nagari. Sesuai dengan apa yang disampaikan oleh (Mardikanto, Prima, Krisnha, \& Aprillia, 2014) pemberdayaan masyarakat adalah masyarakat yang mampu merobah kondisinya ke arah yang lebih baik dari pada sebelumnya dengan kata lain memberdayakan adalah kemampuan memandirikan masyarakat.

\section{Ketepatan Sasaran Program PUAP dalam Memberdayakan Masyarakat Miskin di Kabupaten Pesisir Selatan}

Mengukur efektivitas program dalam suatu lembaga mengacu kepada ketepatan sasaran program PUAP.
Sasaran program adalah berkembangnya usaha pelaku agribisnis yang mempunyai usaha harian, mingguan, maupun musiman. Sejalan dengan itu (Richard, 1985) mengemukakan bahwa efektivitas ditinjau dari sudut pencapaian tujuan, dimana keberhasilan suatu organisasi harus mempertimbangkan bukan saja sasaran organisasi tetapi juga mekanisme mempertahankan diri dalam mengejar sasaran.

Usaha tanaman pangan pada gabungan kelompok tani Taluak Tigo Sakato dengan gabungan kelompok tani Semedang telah efektif dan telah tepat sasaran, di buktikan dengan masyarakat yang telah dapat merasakan manfaat dari program PUAP dan juga telah dapat membantu masyarakat memudahkan dalam mengelola sawahnya. Sebagaimana yang dijelaskan dalam teori (Cambel, 1989) bahwa ketepatan sasaran yaitu apabila tujuan tercapai dan tepat pada sasaran yang dituju maka suatu kegiatan dapat dikatakan efektif.

Pada gabungan kelompok tani Taluak Tigo Sakato dan Semedang telah tepat kepada sasaran program PUAP yaitu berkembangnya usaha pelaku agribisnis. Tanaman pangan yang dimodali program PUAP ini adalah berkembangnya usaha pelaku agribisnis musiman yaitu tanaman padi ke sawah dan usaha harian seperti menjual lontong, membuat keripik serta membuat kue talam. Sementara gabungan kelompok tani Pincuran Bersama belum dapat mengembangkan usaha pelaku agribisnis harian, mingguan, bulanan maupun musiman. Hal ini disebabkan gabungan kelompok tani Pincuran Bersama tidak tepat sasaran dalam penyaluran dana PUAP. 
Kepuasan Terhadap Program PUAP dalam Memberdayakan Masyarakat Pesisir Selatan

Kepuasan yang dimaksud adalah kepuasan terhadap program PUAP dalam memberdayakan masyarakat baik dari diri anggota maupun dari pihak PUAP. Dalam memberdayakan masyarakat miskin Pesisir Selatan program PUAP telah melakukan berbagai kegiatan dengan cara memberikan bantuan pinjaman modal, sosialisasi tentang pinjaman dan ilmu pertanian. Pemberian pinjaman tersebut diberikan kepada dua jenis usaha yaitu usaha budidaya (tanaman pangan), dan usaha non budidaya (industri rumah tangga).

Gabungan kelompok tani Taluak Tigo Sakato dan Semedang telah mampu memberikan hasil yang bagus kepada PUAP dimana dana telah tersalurkan kepada masyarakat. Selain itu, gabungan kelompok tani Taluak Tigo Sakato telah mampu menambah asetnya menjadi lebih banyak sehingga gabungan kelompok tani ini dengan banyaknya asset makin banyak pula dapat membantu masyarakat miskin di Pesisir Selatan. Untuk usaha tanaman pangan ini gabungan kelompok tani Taluak Tigo Sakato dan gabungan kelompok tani Semedang telah dapat membantu masyarakat keluar dari kemiskinannya. Selain itu untuk program usaha tanaman pangan ini merupakan usaha yang anggotanya paling banyak. Pihak PUAP sangat berterimah kasih kepada ketua gabungan kelompok tani dan menejer LKM-A yang telah mampu menjalankan dana PUAP dengan baik. Kepuasan terhadap program merupakan kepuasan terhadap kegiatan. Artinya, jika kegiatan telah berhasil dilaksanakan dan tepat sasaran karena masyarakat secara umum dapat merasakan kepuasan bersama. Karena telah berhasil keluar dari kemiskinan mereka.

\section{Keberhasilan Kegiatan Program PUAP dalam Memberdayakan Masyarakat Miskin di Kabupaten Pesisir Selatan}

Salah satu ukuran untuk melihat keberhasilan dari pelaksanaan suatu program dengan merujuk kepada hasil akhir dari program itu sendiri. Menurut Budiani untuk mengukur efektivitas suatu program dapat dilakukan dengan melihat sejauhmana kesesuaian antara hasil pelaksanaan program dengan indikator keberhasilan program yang telah ditetapkan sebelumnya (Budiani, 2009). Adapun indikator keberhasilan program PUAP dengan melihat meningkatnya jumlah anggota petani yang mendapat bantuan modal dan meningkatnya pendapatan petani (Pedoman PUAP, 2010).

Gabungan kelompok tani yang mendapat bantuan PUAP terlihat bahwa mereka telah berhasil membuktikan diri menjadi kelompok tani yang maju dan siap setiap tahunnya untuk melakukan kemajuan dan mencapai keberhasilan. Melalui program tersebut masyarakat diberi ilmu tentang menanam padi dengan cara tanam SRI (the System Rice of Intensification). Hari ini masyarakat telah merasakan manfaatnya. Dalam setiap satu hektar setiap kelompok tani/petani memperoleh hasil panen mencapai 3 ton dalam sekali panen (4 bulan). Artinya pendapatan merekapun jadi bertambah jika dilihat pada hasil panen sebelum mengikuti program.

Contoh hitungan pendapatan tanaman padi masyarakat sebelum 
mengikuti program tanam Sri (the System Rice of Intensification) ini, dalam 1 (ha) hanya mendapatkan hasil lebih kurang 2 ton (cara tanam tradisional). 2 ton $=33$ karung $\times 340=11.300 .000$ sekali panen $(4$ bulan) dan petani hanya mendapatkan 2.825.000/bulan. Rata-rata petani hanya memiliki lahan atau sawah hanya 1/2 (ha) jadi jika diuangkan pendapat petani hanya 1.412.500-, /bulan. Bandingkan dengan pendapatan setelah mengikuti program, pendapatan masyarakat mencapai 3 ton $=50$ karung disebabkan 1 karung padi adalah $60 \mathrm{Kg}$. dan harga 1 karung 340.000, jadi $50 \times 340.000=$ 17.000.000/4 bulan dalam 1 (ha). Jadi dalam 1 bulan petani bisa menghasilkan uang sebanyak 4.250.000-/ha. Jika masyarakat mempunyai paling sedikit lahan sawah setengah hekatar ( $1 / 2$ ha), maka masyarakat telah berhasil mengantongi uang sebanyak 8.500.000-,/4 bulan, dan dalam satu bulan berarti masyarakat telah mendapatkan 2.125.000-.

Apabila melihat peningkatan hasil panen padi masyarakat dari tanam tradisional menjadi tanam Sri maka memiliki selisih sebanyak 1 ton/ha, dan jika diuangkan berarti masyarakat mendapatkan uang sebanyak 1 ton $=16$ karung padi. 16 karung x 340.000 (harga padi/karung) $=5.440 .000-$, dalam sekali panen (4 bulan). Berarti dalam satu bulan masyarakat petani telah berhasil mendapatkan uang sebanyak 1.360.000/ha. Peningkatan pendapatan seperti ini jelas sangat membantu perbaikan pendapatan masyarakat. Bagi masyarakat yang memiliki lahan $1 / 2$ ha berarti sudah mendapatkan peningkatan sebesar 680.000-, dalam satu bulan. Pada masyarakat perdesaan peningkatan pendapatan ini sangat berpengaruh terhadap kehidupan sehari-harinya disebabkan pengeluaran atau sesuatu yang dibeli masyarakat daerah tidak semahal di perkotaan. jadi terlihat manfaat masyarakat petani melakukan cara tanam SRI.

Sehubungan dengan hal di atas, sesuai dengan ketentuan Badan Statistika Kabupaten Pesisir Selatan program PUAP telah dapat membantu masyarakat keluar dari garis kemiskinan. Sebab jika diukur dari pendapatan perbulan masyarakat telah melebihi kapasitas pendapatan terendah masyarakat miskin di kabupaten Pesisir Selatan yaitu 1.500.000/bulan. Jika pendapatan masyarakat kurang dari 1.500.000/bulan maka masyarakat tersebut termasuk tergolong masyarakat miskin. Menurut ilmu manajemen antara perencanaan dan pengawasan/ penegendalian sering dikatakan sebagai dua sisi dari keping uang yang sama. Dikatakan demikian, karena sebelum pelaksanaan kegiatan diperlukan adanya perencanaan yang matang, dan sebaliknya, agar hasil dan proses pelaksanaan kegiatan sesuai dengan yang direncanakan, mutlak diperlukan adanya pengendalian kegiatan (Mardikanto et al., 2014).

Gabungan kelompok tani Taluak Tigo Sakato dan Semedang telah mampu mempersiapkan perencanaan yang matang sehingga dapat meraih hasil dari usahanya. Tercapainya tujuan program dengan baik dalam usaha tanaman pangan dan industri rumah tangga yang ditandai dengan meningkatnya pendapatan hasil tanam padinya dari sebelum mengikuti program. Bertambahnya masyarakat yang bergabung dengan kelompok tani Taluak Tigo Sakato karena semakin banyaknya anggota berarti semakin banyak juga 
masyarakat yang terbantu. Pada usaha industri rumah tangga dibuktikan dengan semakin banyaknya anggota kelompok tani usaha industri rumah tangga. Adanya olahan hasil industri rumah tangga pertanian ibuk-ibuk gabungan kelompok tani Semedang yang di pasarkan dimasyarakat yaitu keripik lento yang telah dapat membantu masyarakat keluar dari garis kemiskinan.

Menurut (Mardikanto et al., 2014) masyarakat yang berdaya adalah masyarakat yang mampu merobah kondisinya ke arah yang lebih baik dari pada sebelumnya. Artinya, memberdayakan adalah kemampuan memandirikan masyarakat. Dalam hal ini gabungan kelompok tani Taluak Tigo Sakato dengan gabungan kelompok tani Semedang telah mampu memandirikan masyarakat ke arah yang lebih baik.

\section{KESIMPULAN}

Efektivitas program Pengembangan Usaha Agribisnis Perdesaan (PUAP) dalam memberdayakan masyarakat miskin di Kabupaten Pesisir Selatan melalui pemberdayaan gabungan kelompok tani setempat secara umum terlihat efektif. Hal tersebut terbukti dari 3 gabungan kelompok tani yang mendapat bantuan program PUAP dari kementerian Pertanian hanya satu yang tidak sesuai atau tepat sasaran. Pada usaha tanaman pangan dengan meningkatkanya pendapatan masyarakat melalui cara tanam padi dengan tanam SRI (system rice intentisification) dari sebelum mengikuti program. Pada usaha industri rumah tangga dibuktikan dengan semakin banyaknya anggota kelompok tani usaha industri rumah tangga. Selain itu, adanya olahan hasil industri rumah tangga pertanian ibuk-ibuk gabungan kelompok tani yang di pasarkan masyarakat seperti keripik lento yang ternyata dapat membantu meningkakan sumber pendapatan masayarakat miskin di Pesisir Selatan. Sedangkan gabungan kelompok tani yang belum berhasil meningkatkan pendapatan mereka disebabkan oleh ketidakmauan masyarakat berubah dan memahami tentang pentingnya program pemberdayaan pemerintah tersebut. Hal itu ditunjukan dengan penyalahgunaan bantuan yang seharusnya untuk kegiatan produktif berubah menjadi konsumtif. Oleh karena itu perlu sosialisasi lebih lanjut dari pemerintah.

\section{REFERENSI}

astuti, W. (2015). Analisis Pengaruh Kinerja Keuangan Terhadap Pertumbuhan Ekonomi Dan Dampaknya Terhadap Pengangguran Dan Kemiskinan (Studi Pada Kabupaten Dan Kota Di Pulau Jawa Periode 2007-2011). Ebbank, 6(1), 1-18.

Budiani, N. W. (2009). Efektivitas Program Penanggulangan

Pengangguran Karang Taruna" Eka Taruna Bhakti" Desa Sumerta Kelod Kecamatan Denpasar Timur Kota Denpasar. Input: Jurnal Ekonomi Dan Sosial, 1(2).

Cambel, J. P. (1989). Riset Dalam Efektivitas Organisasi, Terjemahan Salut Simamora. Jakarta, Erlangga. 
Dewi, N., Yusuf, Y., \& Iyan, R. Y. (2017).

Pengaruh Kemiskinan Dan Pertumbuhan Ekonomi Terhadap Indeks Pembangunan Manusia Di Provinsi Riau. Jurnal Online Mahasiswa Fakultas Ekonomi Universitas Riau, 4(1), 870-882.

Mardikanto, T., Prima, N. G., Krisnha, A.

S., \& Aprillia, T. (2014). Pembangunan Berbasis Masyarakat. Alpabeta, Bandung.

Miradj, S., \& Sumarno, S. (2014). Pemberdayaan Masyarakat Miskin, Melalui Proses Pendidikan Nonformal, Upaya Meningkatkan Kesejahteraan Sosial Di Kabupaten Halmahera Barat. Jppm (Jurnal Pendidikan Dan Pemberdayaan Masyarakat), 1(1), 101-112.

Mustikawati, I. (2010). Model Pendidikan Kewirausahaan Bagi Pengangguran Perkotaan Penduduk Asli Miskin Kota Yogyakarta. Jurnal Kependidikan: Penelitian Inovasi Pembelajaran, 40(1).

Mustikawati, R. I., Si, M., Baswedan, A. R., \& Sumardiningsih, S. (N.D.). The Model Of Entrepreneurship Education For Unemployment Urban Community In Poor Indigeneous Inhabitants In The City Of Yogyakarta.

Narutomo, T. (2014). Program Penguatan Sistem Inovasi Daerah (Sida) Sebagai Exit Strategy Program Nasional Pemberdayaan Masyarakat (Pnpm). Jurnal Bina Praja: Journal Of Home Affairs Governance, 6(2), 143-156.
Rahmatika, A. (2018). Kinerja Dinas Sosial Dalam Penanganan Gelandangan dan Pengemis Di Kota Cilegon (PhD Thesis). Perpustakaan.

Richard, M. (1985). Efektifitas Organisasi. Jakarta: Erlangga.

Sadiyah, Y. H., \& Arianti, F. (2012). Analisis kemiskinan rumah tangga melalui faktor-faktor yang mempengaruhinya di Kecamatan Tugu Kota Semarang (PhD Thesis). Fakultas Ekonomika dan Bisnis.

Sudarsana, I. K. (2016). Peningkatan Mutu Pendidikan Luar Sekolah Dalam Upayapembangunan Sumber Daya Manusia. Jurnal Penjaminan Mutu, 1(1), 1-14.

Suoth, N., Tinangon, J., \& Rondonuwu, S. (2016). Pengukuran efisiensi dan efektivitas pengelolaan keuangan daerah pada Dinas Pengelola Keuangan, Pendapatan Dan Aset (DPKPA) kabupaten minahasa selatan. Jurnal EMBA: Jurnal Riset Ekonomi, Manajemen, Bisnis Dan Akuntansi, 4(1).

Sururi, A. (2017). Pemberdayaan masyarakat melalui program pembangunan infrastruktur perdesaan dalam meningkatkan kesejahteraan masyarakat Kecamatan Wanasalam Kabupaten Lebak. Sawala: Jurnal Administrasi Negara, 3(2). 
Wijayanto, R. D., \& Arianti, F. (2010). Analisis pengaruh PDRB, pendidikan dan pengangguran terhadap kemiskinan di kabupaten/kota Jawa Tengah Tahun 2005-2008 (PhD Thesis). Universitas Diponegoro. 
46 || Turast: Jurnal Penelitian dan Pengabdian Vol. 6, No. 1, Januari-Juli 2018 
